\title{
EFFECTS OF SPECIALIZED PHYSICAL EDUCATION AND ADDITIONAL AEROBIC TRAINING ON AEROBIC ENDURANCE OF POLICE STUDENTS
}

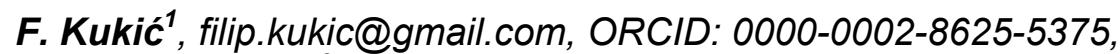 \\ N.Koropanovski², nenad.koropanovski@kpu.edu.rs, ORCID: 0000-0002-7196-7185, \\ R. Janković2 ${ }^{2}$ radivoje.jankovic@kpu.edu.rs, ORCID: 0000-0002-8902-2737, \\ M. Dopsaj, ${ }^{1,3}$, milivoj.dopsaj@gmail.com, ORCID: 0000-0001-7153-2993 \\ ${ }^{1}$ University of Belgrade, Belgrade, Serbia, \\ ${ }^{2}$ University of Criminal Investigation and Police Studies, Belgrade, Serbia, \\ ${ }^{3}$ South Ural State University, Chelyabinsk, Russian Federation
}

\begin{abstract}
Aim. The aim of this study was to investigate if the SPE classes were sufficient to improve the police students' aerobic endurance over the period of 12 weeks; and to investigate if two additional aerobic trainings per week may have an effect on the students' aerobic endurance. Materials and Methods. An initial and final estimated maximal oxygen consumption of 233 ( 987 and $\widehat{\jmath} 146)$ police students were assessed at the begging and after 12 weeks of training. All participants were performing SPE classes as part of the curriculum, while experimental groups $(\& 39$ and $\delta 81$ ) conducted two additional trainings for aerobic endurance. A repeated-measure analysis of variance was used to analyze the effects of the treatments and the differences between the treatments. Results. The SPE with two additional aerobic endurance trainings significantly improved students' aerobic endurance in both sexes $(14 \%, \mathrm{p}<0.01)$. Two aerobic trainings alone had large effects on aerobic endurance female $(11.66 \%, \mathrm{p}<0.01)$ and male $(12.15 \%, \mathrm{p}<0.01)$ police students. Conclusions. Relatively simple aerobic training, applied two times per week, could provide meaningful changes in aerobic endurance. Practitioners could use the period while police students are at the university to educate them on how to organize and conduct basic physical training on their own.
\end{abstract}

Keywords: police cadets, law enforcement, aerobic fitness, physical education.

\section{Introduction}

Aerobic endurance has been identified as a good predictor of performance in job-related physical tests for tactical occupations [1] such as police officers [14], correctional officers [13], and firefighters [18]. Aerobic endurance has been identified as a good predictor of performance in job-related physical tests for police officers [14], correctional officers [13], and firefighters [18]. In contrast, lower levels of aerobic endurance have been associated with increased risk of premature death from all causes [19] as well as with dropout rate from police academy and increased number of injuries in police officers [17]. Considering the importance for police students and officers, aerobic endurance has been an integral part of the recruitment and educational process of police students, and their career once they graduated and became officers [8,9].

However, police students have often been loaded with the curricula that include a big proportion of theoretical exams, whose preparation requires considerable amount of time spent in seated position being physically inactive. Moreo- ver, during the educational process, physical education of police students dominantly focuses on defensive tactics, self-defense, and use of force that normally consists of short bouts of high intensity activity followed by long verbal explanations. This type of physical activity may not be sufficient for development of students' aerobic endurance. Similarly, the biggest proportion of duty time, the work of police officers have been sedentary in nature such as deskwork, sitting in a parked car, standing on the street or low intensity walking $[11,16,22]$. This pattern of sedentary duty with occasional physically demanding tasks has been taking its toll as health-related physical fitness of police officers was shown to decrease by the time spent in service $[4,21]$.

Given that the goal of police agencies has been to predict and prevent the potential problems, the curriculum for higher education of police students includes the subjects of law, criminal, social, and forensic sciences, which often comprise the greater share of the curriculum comparing to physical education classes [10, 25]. The main reason for this lies in a total number of 
designated classes that need to be split to all subjects, whereby the split is not equal but rather depends on the number of cumulative points that each subject takes. For example, the curriculum of the University of Criminal Investigation and Police Studies (UCIPS) from Serbia includes four Specialized Physical Education (SPE) classes per week, one theoretical and three practical. The curriculum of SPE is conducted through three semesters, where the majority of curriculum of practical SPE consists of martial arts (Karate, Judo, Jujutsu) in forms of defensive tactics and use of force. The students are taught through three levels, getting familiar with basic techniques (SPE 1), their use in controlled conditions (SPE 2), and their situational usage (SPE 3) [2, 9]. In contrast, strength and conditioning take a small amount of the classes at the begging of the studies (first semester), where the students are introduced with basic methods of physical preparation. In that regard, one may argue as if the frequency and volume of aerobic training within the UCIPS curricula have not been sufficient to improve aerobic endurance of police students.

The rationale for improvement or maintenance of aerobic endurance of police students at certain level lies in facts that it has been one of the main (if not the most important) factors of performance-related and health-related physical fitness. Thus, the aim of this study was to investigate if the SPE classes were sufficient to improve the police students' aerobic endurance over the period of 12 weeks; and to investigate if two additional aerobic trainings per week may have an effect on the students' aerobic endurance.

\section{Materials and Methods}

\section{Participants}

This study included cohort of 233 police students of both sexes ( $\$ 87$ and $\$ 146)$ from the UCIPS. For the purposes of this study, the female and male police students were divided into control and experimental groups. The control group of female police students (c-FPS, $\mathrm{n}=48$, age $=$ $=21.5 \pm 0.6$ years, body height $[\mathrm{BH}]=170.4 \pm$ $\pm 4.7 \mathrm{~cm}$, body mass $[\mathrm{BM}]=63.3 \pm 6.8 \mathrm{~kg}$ ) and male police students (c-MPS, $\mathrm{n}=65$, age $=21.7 \pm$ \pm 0.8 years, $\mathrm{BH}=182.3 \pm 6.3 \mathrm{~cm}$ and $\mathrm{BM}=82.5 \pm$ $\pm 9 \mathrm{~kg}$ ) were doing regular classes of SPE. The experimental group of female police students ([e-FPS], $\mathrm{n}=39$, age $=21.6 \pm 1$ years, $\mathrm{BH}=$ $=168.4 \pm 5.1 \mathrm{~cm}$, and $\mathrm{BM}=65.1 .3 \pm 8 \mathrm{~kg}$ ) and male police students ([e-MPS], $\mathrm{n}=81$, age $=21.8 \pm$ \pm 1.1 years, $\mathrm{BH}=182.8 \pm 6.1 \mathrm{~cm} ; \mathrm{BM}=81.7 \pm$ $\pm 11.4 \mathrm{~kg}$ ) were doing additional two aerobic en- durance trainings per week. The research was carried out according to the Declaration of Helsinki [5], and with the permission of the Ethics Committee of the University of Criminal Investigation and Police Studies in Belgrade.

\section{Testing procedure}

General aerobic endurance was estimated using a 12-minute Cooper running test, whereby the participants were required to cover the longest possible distance in 12 minutes. The subjects run around the 400-m long circuit. During the test, the participants were verbally encouraged and motivated in order to minimize the pacing. All subjects were tested two times (Table 1), one time at the beginning of the study semester and second time at the end of the semester (i.e., after three months). The test and retest defined the initial and final level of aerobic endurance of c-FPS, c-MPS, e-FPS, and e-MPS.

Table 1

\begin{tabular}{|l|l|l|l|}
\hline Groups & Initial & Experimental treatment & Final \\
\hline \multirow{2}{*}{ FPS } & c-FPS & SPE & c-FPS \\
\cline { 2 - 4 } & e-FPS & SPE + aerobic training & e-FPS \\
\hline \multirow{2}{*}{ MPS } & c-MPS & SPE & c-MPS \\
\cline { 2 - 4 } & e-MPS & SPE + aerobic training & e-MPS \\
\hline
\end{tabular}

\section{Training program}

All cadets were attending three practical classes and one theoretical class per week of SPE as part of the UCIPS' curricula. The study lasted for 12 weeks and all subjects completed 36 practical SPE classes. Practical classes of SPE at third year of studies consist of defensive techniques and use of force in simulated real life situations, using the elements of martial arts such as judo, karate and jujutsu. A 45-min SPE classes were intertwined with thorough analyses and explanations of potential situation followed by multiple trails to learn and automatize the response on such or similar situations. The practices of technical elements were conducted with moderate to maximal intensity, while the duration was short, employing mostly phosphagen metabolic systems. Thus, the physical activities during the classes were of moderate to maximal intensity and relatively low volume and therefore total load of the class might not be enough for development of aerobic endurance. Considering this, an additional aerobic training was introduced to experimental group of police students. Students who were actively involved in sport activities were not included in the study. 


\section{Спортивная тренировка}

The experimental groups of cadets (e-FPS and e-MPS) were performing two additional aerobic endurance training sessions per week, for 12 weeks. The first session in the week was organized at the UCIPS and cadets were required to do the repeated high intensity runs. The intensity was controlled by the SIGMA heart rate (HR) monitors (Sigma Electro GmbH, Germany) attached to their chest. The e-FPS run $850 \mathrm{~m}$ and e-MPS run $1000 \mathrm{~m}$ with an intensity of 75-100\% of an estimated HR maximum (Est_HRmax). Since the designated time from the SPE 3 class for this training was about 22 minutes, these distances and intensity were chosen as they approximately correspond to four min interval that was found to be effective in improvement of aerobic endurance [12]. This way, the students would cover about 12 minutes in intensities higher than they could run during the Cooper test. The Est_HRmax was calculated using the formula $(209-0.7 *$ age), in which the age alone explained about $80 \%$ of the variance, while gender was not significant predictor [24].

The second training, experimental groups conducted after they rested for 72 hours. They performed a continuous 30-min running of somewhat hard to moderately hard intensity according to Borg scale $[3,20]$. These intensities assumingly corresponded to about $70-80 \%$ of the Est_HRmax or about $150-160$ beats per minute as correlation between the RPE and HR was recently reported to be high $(r=0.729$, $\mathrm{p}<0.001)$ [26]. The rationale for using the Borg scale lies in a fact that the police agencies often do not have logistical support and necessary strength and conditioning specialists to provide physical preparation to employees. Therefore, being able to understand and use simple tools to perform the basic strength and conditioning on their own could be very useful for both police officers and police agencies.

\section{Statistics}

All data were analyzed using the descriptive statistics to calculate the basic parameters such as mean standard and deviation (SD). Multivariate analysis of variance (MANOVA) was used to evaluate the differences between the control and experimental groups in anthropometrics and aerobic endurance at an initial testing. A repeated measure ANOVA was used to calculate the effects of applied trainings on the Est. $\mathrm{VO}_{2 \max }$, with the significance level set at $p<0.05$ a priori. The relative effects were also expressed in rela- tion to initial values (\%). The magnitude of these effects was calculated using a Cohen's effect size (ES), which were defined as small $=0.2$, moderate $=0.5$, large $=0.8$ and very large $=1.3$ [23] .

\section{Results}

The main characteristics of control and experimental groups of FPS and MPS did not differ significantly in $\mathrm{BH}, \mathrm{BM}$ and $\mathrm{BMI}$ at an initial testing $(\mathrm{p}=0.66-1.00)$. The descriptive statistics for the mean and standard deviation of the Est. $\mathrm{VO}_{2 \max }$ at the initial and final test for each investigated group is presented in Table 2 . The MANOVA analysis showed that there was no difference between the control and experimental groups at an initial testing for FPS $(\mathrm{p}=0.819)$ and MPS $(p=0.695)$ in the Est. $\mathrm{VO}_{2 \max }$. However, significant interaction between the applied trainings and groups occurred in FPS (Wilks' lambda $=0.666, \mathrm{~F}=41.067, \mathrm{p}<0.001)$ and MPS (Wilks' lambda $=0.537, \mathrm{~F}=122.616, \mathrm{p}<0.001)$.

Table 2

\begin{tabular}{|c|c|c|c|}
\hline \multicolumn{4}{|c|}{$\begin{array}{l}\text { Descriptive statistics for Est. } \mathrm{VO}_{2 \max } \\
\text { at the initial and final test }\end{array}$} \\
\hline \multirow{2}{*}{ Variable } & \multirow{2}{*}{ Groups } & Initial & Final \\
\hline & & Mean \pm SD & Mean $\pm \mathrm{SD}$ \\
\hline \multirow{4}{*}{$\begin{array}{l}\text { Est. } \mathrm{VO}_{2 \max } \\
(\mathrm{ml} / \mathrm{kg} / \mathrm{min})\end{array}$} & c-FPS & $35.63 \pm 4.44$ & $36.24 \pm 4.07$ \\
\hline & c-MPS & $45.29 \pm 3.54$ & $45.84 \pm 3.89$ \\
\hline & e-FPS & $35.42 \pm 4.15$ & $40.37 \pm 4.27$ \\
\hline & e-MPS & $45.01 \pm 4.82$ & $51.31 \pm 3.73$ \\
\hline
\end{tabular}

The actual SPE curriculum alone did not have significant effects on the Est. $\mathrm{VO}_{2 \max }$ of both, FPS and MPS, while SPE with additional aerobic endurance trainings had a positive large and very large effect on the Est. $\mathrm{VO}_{2 \max }$ of FPS and MPS, respectively (Table 3). The magnitude of effects was slightly higher in MPS comparing to FPS. However, the relative training effects were the same in FPS and MPS (Fig. 1a and 1b).

The absolute effects of applied trainings and their effect sizes

\begin{tabular}{|c|c|c|c|c|c|c|}
\hline \multirow[b]{2}{*}{ Variable } & \multirow[b]{2}{*}{ Group } & \multirow{2}{*}{\begin{tabular}{|l|} 
Mean \\
diffe- \\
rence
\end{tabular}} & \multirow[b]{2}{*}{ SE } & \multicolumn{2}{|c|}{$95 \% \mathrm{CI}$} & \multirow[b]{2}{*}{ ES } \\
\hline & & & & LB & UB & \\
\hline \multirow{4}{*}{$\begin{array}{l}\text { Est. } \mathrm{VO}_{2 \max } \\
(\mathrm{ml} / \mathrm{kg} / \mathrm{min})\end{array}$} & c-FPS & .61 & .46 & -1.52 & \begin{tabular}{|l|}
0.30 \\
\end{tabular} & 0.14 \\
\hline & c-MPS & .55 & .39 & -1.31 & 0.22 & 0.16 \\
\hline & e-FPS $* *$ & 4.95 & .50 & -5.95 & -3.95 & 1.19 \\
\hline & e-MPS** & \begin{tabular}{|l|}
6.30 \\
\end{tabular} & .35 & -6.99 & -5.62 & 1.31 \\
\hline
\end{tabular}

SE - standard error, CI - confidence interval, LB - lower bound, UB - upper bound, ES - effect size. ${ }^{* *}$ Significant at $\mathrm{p}<0.001$. 

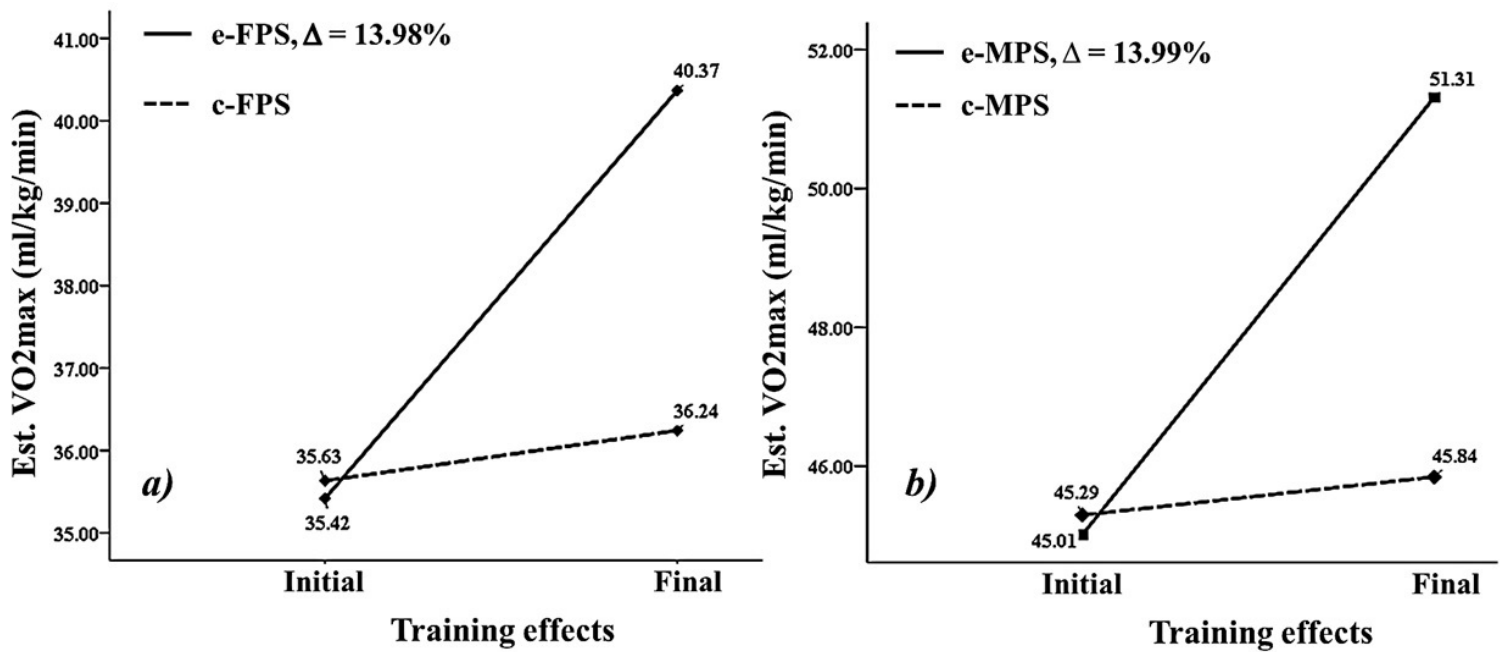

Fig. 1. Relative $(\Delta)$ training effects of applied trainings on control and experimental groups of FPS (a) and MPS (b)

The differences between the effects of SPE and SPE with aerobic training

Table 4 on aerobic endurance of FPS and MPS

\begin{tabular}{|l|c|c|c|c|c|}
\hline \multirow{2}{*}{ Group } & Difference between & \multirow{2}{*}{ SE } & \multicolumn{2}{|c|}{$95 \% \mathrm{CI}$} & \multirow{2}{*}{ ES } \\
\cline { 4 - 5 } & the training effects & & LB & UB & \\
\hline FPS** & $4.13 \mathrm{ml} / \mathrm{kg} / \mathrm{min}$ & 0.912 & 2.31 & 5.94 & 1.05 \\
\hline MPS** & $5.47 \mathrm{ml} / \mathrm{kg} / \mathrm{min}$ & .637 & 4.211 & 6.730 & 1.15 \\
\hline
\end{tabular}

$\mathrm{SE}$ - standard error, CI - confidence interval, LB - lower bound, UB - upper bound, ES - effect size. $* *$ Significant at $\mathrm{p}<0.001$

Considering the difference between the effects of the SPE and SPE with additional aerobic training at the final test, the results revealed a significant difference between these two treatments in both FPS and MPS (Table 4). Thus, the magnitude of aerobic training separately was slightly lower when adjusted for the SPE.

\section{Discussion}

The main findings of this study showed that the SPE curriculum was not sufficient to improve the aerobic endurance of police students, regardless of sex. In contrast, the SPE with two additional aerobic endurance trainings significantly improved aerobic fitness of both FPS and MPS. Moreover, two aerobic trainings alone had large effects on aerobic endurance, even though only one training was in controlled conditions (i.e., intensity $75-100 \%$ of Est_HRmax) and the other training students conducted on their own, following the given instructions (i.e., certain RPE). Thus, it seems that the physical education professors and teachers can influence police students' aerobic endurance by rearranging the time within the classes and by teaching students how to use the established scientific information in conducting aerobic training on their own.

Several studies investigated the effects of academy training on components of police stu- dents' physical fitness such as aerobic endurance and muscular endurance [6-8]. Cocke et al. [6] found that randomized training significantly affected the time needed to complete $2.4-\mathrm{km}$ run test $(\Delta=11.32 \%, \mathrm{ES}=1.01, \mathrm{p}<0.01)$, while periodized program did not. Crawley et al. [7] found significant improvements $(\Delta=4.6 \%$, $\mathrm{p}<0.01)$ in aerobic endurance (15 round trips between 2 cones placed 88 feet apart) at the end of a 16-week training period. The trainings were consisted of aerobic, plyometrics, body weight, and resistance exercises, and the aerobic endurance was incorporated in every training session. Čvorović et al. [8] investigated the effects of a 12-week training course (two 6-week mesocycles) on body composition and physical fitness components such as muscular endurance and aerobic endurance. Authors found significant changes in aerobic fitness over the first 6-week mesocycles $(\Delta=11.39 \%, \mathrm{p}<0.01)$ as well as over the second 6-week mesocycles $(\Delta=4.49 \%$, $\mathrm{p}<0.01$ ), which in total counted for $15.77 \%$ $(p<0.01)$ of increase in aerobic endurance (i.e., 2.4-km run).

These results suggest that differently planned, organized and applied training programs led to similar improvements in aerobic endurance of police students whenever the aerobic component 


\section{Спортивная тренировка}

of training was consistently present. Given that our students had similar improvements, it seems that even two aerobic trainings per week, if conducted regularly, may be sufficient to improve aerobic endurance. However, this may as well depend on an initial level of aerobic endurance that can be attributed to the lack of aerobic endurance training within the study curricula.

The results from our study are in line with the existing evidence on police students suggesting that only a permanent aerobic training positively affect aerobic endurance. In that regard, both experimental groups in our study reached over $70^{\text {th }}$ percentile of Serbian population' Est. $\mathrm{VO}_{2 \max }$ [2]. Furthermore, students in average improved aerobic endurance from fair (i.e., $40-50^{\text {th }}$ percentile) to good (i.e., $60-65^{\text {th }}$ percentile) according to the scale of American College of Sports Medicine [19]. In contrast, aerobic fitness of control groups remained the same suggesting that they might leave the academy with poor or fair aerobic endurance if additional aerobic training was not applied. It seems that two aerobic endurance trainings per may be a minimal frequency sufficient to provide improvements in students fair aerobic endurance.

The limitation to this study was that measures such as those for maximum strength, agility, flexibility, and functional mobility were not available and therefore the effects of SPE on these measures were not defined. Using these measures in future studies would be beneficial in improving physical education curriculum of police students in attempt to meet the occupational performance and good health. Furthermore, nutritional status and hydration status were not controlled and they may have had an impact on testing performance and on body composition such as reduction in body weight due to training followed by lower calorie intake [15].

\section{Conclusions}

In conclusion, this research demonstrated that relatively simple training program could provide meaningful changes in aerobic endurance, which justifies the inclusion of this type of training with police students. The practitioners should be sensitive to the challenges and constraints that the police students and officers may face and plan physical training accordingly. Moreover, practitioners could use the educational period (i.e., while at the university, college or academy) to educate police students how to use certain training tools so they can organize and conduct basic physical training on their own. This bears practical importance because agencies are often limited with time, work force and resources to provide physical training for students and/or officers.

\section{Acknowledgments}

This research was part of the National Scientific Project "Effects of applied physical activity on locomotor, metabolic, psychological, social and educational status of the population of the Republic of Serbia", No. ID III47015, and it is financed by the Ministry of Education, Science and Technological Development of the Republic of Serbia.

\section{References}

1. Alvar B., Sell K., Deuster P.A. (Eds.) NSCA's Essentials of Tactical Strength and Conditioning [Internet]. Champaign, IL: Human Kinetics; 2017. 677 p. Available at: https://lccn. loc.gov/2016035892.

2. Blagojević M., Vučković G., Koropanovski N., Dopsaj M. Specijalno fizičko obrazovanje II: Usmereni nivo. Beograd, RS: Kriminalističko Policijska Akademija; 2016. 212 p. (in Serbian)

3. Borg G.A. Psychophysical Bases of Perceived Exertion. Medicine Science in Sports Exercise, 1982, vol. 14, no. 5, pp. 377-81. DOI: 10.1249/00005768-198205000-00012

4. Boyce R.W., Jones G., Lloyd C. A Longitudinal Observation of Police: Body Composition Changes over 12 Years with Gender and Race Comparisons. Journal of Exercise Physiology Online, 2008, vol. 11, no. 6, pp. 1-13.

5. Christie B. Doctors Revise Declaration of Helsinki. BMJ: British Medical Journal. 2000, vol. 321, no. 7266 , pp. 913 . DOI: $10.1136 / \mathrm{bmj}$. 321.7266 .913

6. Cocke C., Dawes J., Orr R.M. The Use of 2 Conditioning Programs and the Fitness Characteristics of Police Academy Cadets. Journal of Athletic Training, 2016, vol. 51, no. 11, pp. 887-896. DOI: 10.4085/1062-6050-51.8.06

7. Crawley A.A., Sherman R.A., Crawley W.R., Cosio-Lima L.M. Physical Fitness of Police Academy Cadets: Baseline Characteristics and Changes During a 16-week Academy. Journal of Strength and Conditioning Research, 2016, vol. $30, \quad$ no. $5, \quad$ pp. 1416-1424. DOI: 10.1519/JSC.0000000000001229

8. Čvorović A., Kukić F., Orr R.M., Dawes J.J., Jeknić V., Stojković M. Impact of a 12Week Postgraduate Training Course on the Body Composition and Physical Abilities of Police Trainees. Journal of Strength and Conditioning Research, 2018. DOI: 10.1519/JSC. 0000000000002834

9. Demling R.H., DeSanti, L. Effect of a Hypocaloric Diet, Increased Protein Intake and 
Resistance Training on Lean Mass Gains and Fat Mass Loss in Overweight Police Officers. Annals of Nutrition and Metabolism, 2000, vol. 44, no. 1, pp. 21-29. DOI: 10.1159/000012817

10. Dimitrijević R., Koropanovski N., Dopsaj M., Vučković G., Janković R. The Influence of Different Physical Education Programs on Police Students' Physical Abilities. Policing: An International Journal of Police Strategies \& Management, 2014, vol. 37, no. 4, pp. 794-808. DOI: 10.1108/PIJPSM-05-2014-0060

11. Fahsing I., Ask K. The Making of an Expert Detective: the Role of Experience in English and Norwegian Police Officers' Investigative Decision-Making. Psychology, Crime \& Law, 2016, vol. 22 , no. 3, pp. 203-223. DOI: 10.1080/1068316X.2015.1077249

12. Garbarino S., Magnavita N. Work Stress and Metabolic Syndrome in Police Officers. A ProSpective Study. PLoS ONE, 2015, vol. 10, no. 12, pp. 1-15. DOI: 10.1371/journal.pone.0144318

13. Helgerud J., Høydal K., Wang E., Karlsen T., Berg P., Bjerkaas M., Simonsen T., Helgesen C., Hjorth N., Bach R., Hoff J. Aerobic HighIntensity Intervals Improve VO2max More Than Moderate Training. Medicine Science in Sports Exercise, 2007, vol. 39, no. 4, pp. 665-671. DOI: 10.1249/mss.0b013e3180304570

14. Jamnik V.K., Thomas S.G., Shaw J.A., Gledhill N. Identification and Characterization of the Critical Physically Demanding Tasks Encountered by Correctional Officers. Applied Physiology, Nutrition, and Metabolism, 2010, vol. 35, no. 1 , pp. 45-58. DOI: 10.1139/H09-121

15. Kukic F., Dopsaj M., Dawes J., Orr R., Cvorovic A. Use of Human Body Morphology as an Indicator of Physical Fitness: Implications for Police Officers. International Journal of Morphology, 2018, vol. 36, no. 4, pp. 1407-1412. DOI: $10.4067 / \mathrm{S} 0717-95022018000401407$

16. Kukić F., Todorović N., Cvijanović N. Effects of a 6-Week Controlled Exercise Program and Semi-Controlled Diet on Body Fat and Skeletal Muscle Mass in Adults. Human. Sport. Medicine, 2019, vol. 19, no. 1, pp.1-7. DOI: 10.14529/hsm190101

17. Orr R., Dawes J.J., Pope R., Terry J. Assessing Differences in Anthropometric and Fitness Characteristics between Police Academy Cadets and Incumbent Officers. Journal of Strength and Conditioning Research, 2018, vol. 32, no. 9, pp. 2632-2641. DOI: 10.1519/JSC.0000000000002328
18. Orr R., Stierli M., Hinton B., Steele M. The 30-15 Intermittent Fitness Assessment as a Predictor of Injury Risk in Police Recruits. In Australia: Faculty of Health Sciences \& Medicine Publications; 2013, p. 3. Available at: http:// epublications.bond.edu.au/hsm_pubs/627.

19. Perroni F., Tessitore A., Cortis C., Lupo C., D’Artibale E., Cignitti L., Capranica L. Energy Cost and Energy Sources During a Simulated Firefighting Activity. Journal of Strength and Conditioning Research, 2010, vol. 24, no. 12 , pp. 3457-3463. DOI: 10.1519/JSC. 0b013e3181b2c7ff

20. Riebe D., Ehrman J.K., Liguori G., Megal M. ACSM's Guidelines for Exercise Testing and Prescription. 10th ed. Philadelphia, PA: Wolters Kluwer; 2018. 472 p.

21. Scherr J., Wolfarth B., Christle J.W., Pressler A., Wagenpfeil S., Halle M. Associations Between Borg's Rating of Perceived Exertion and Physiological Measures of Exercise Intensity. European Journal of Applied Physio$\log y, 2013$, vol. 113, no. 1, pp. 147-155. DOI: 10.1007/s00421-012-2421-x

22. Sorensen L., Smolander J., Louhevaara V., Korhonen O., Oja P. Physical Activity, Fitness and Body Composition of Finnish Police Officers: A 15-Year Follow-Up Study. Occupational Medicine, 2000, vol. 50, no. 1, pp. 3-10. DOI: $10.1093 /$ occmed/50.1.3

23. Stevens J., Cai J., Pamuk E.R., Williamson D.F., Thun M.J., Wood J.L. The Effect of Age on the Association between Body-Mass Index and Mortality. New England Journal of Medicine, 1998, vol. 338, no. 1, pp. 1-7. DOI: 10.1056/NEJM199801013380101

24. Sullivan G.M., Feinn R. Using Effect Size - or Why the P Value Is Not Enough. Journal of Graduate Medical Education, 2012, vol. 4, no. 3, pp. 279-282. DOI: 10.4300/JGME-D-1200156.1

25. Tanaka H., Monahan K.D., Seals D.R. Age-Predicted Maximal Heart Rate Revisited. Journal of the American College of Cardiology, 2001, vol. 37, no. 1, pp. 153-156. DOI: 10.1016/S0735-1097(00)01054-8

26. Zinoubi B., Zbidi S., Vandewalle H., Chamari K., and Driss T. Relationships between Rating of Perceived Exertion, Heart Rate and Blood Lactate During Continuous and AlternatedIntensity Cycling Exercises. Biology of Sport, 2018, vol. 35 , no. $1, \quad$ pp. 29-37. DOI: 10.5114/biolsport.2018.70749

Received 20 November 2019 


\title{
ВЛИЯНИЕ СПЕЦИАЛИЗИРОВАННОГО ФИЗИЧЕСКОГО ОБРАЗОВАНИЯ И ДОПОЛНИТЕЛЬНОЙ АЭРОБНОЙ НАГРУЗКИ НА АЭРОБНУЮ ВЫНОСЛИВОСТЬ КУРСАНТОВ ПОЛИЦИИ
}

\author{
Ф. Кукич ${ }^{1}$, Н. Коропановски ${ }^{2}$, Р. Янкович ${ }^{2}$, М. Допсай ${ }^{1,3}$ \\ ${ }^{1}$ Белградский университет, г. Белград, Сербия, \\ ${ }^{2}$ Университет уголовных расследований и полицейской подготовки, г. Белград, Сербия, \\ ${ }^{3} Ю$ жн-Уральский государственный университет, г. Челябинск, Россия
}

Цель. Цель данного исследования - определить, хватает ли занятий специализированной физической подготовкой для улучшения аэробной выносливости курсантов полиции за 12 недель, и выяснить, повлияют ли две дополнительные аэробные тренировки в неделю на аэробную выносливость курсантов. Материалы и методы. Исходные и итоговые показатели максимального потребления кислорода были установлены у 233 курсантов полиции (87 девушек и 146 юношей) в начале и через 12 недель тренировок. Все участники занимались специализированной физической подготовкой согласно расписанию, в то время как экспериментальная группа (39 девушек и 81 юноша) посещала две дополнительные тренировки аэробной направленности в неделю. Для анализа воздействия различных режимов тренировок и разницы между ними был использован дисперсионный анализ повторных измерений. Результаты. Специализированная физическая подготовка с двумя дополнительными тренировками аэробной направленности значительно улучшила аэробную выносливость курсантов обоего пола $(14 \%, \mathrm{p}<0,01)$. Две аэробные тренировки, рассматриваемые отдельно, продемонстрировали заметное воздействие на аэробную выносливость у девушек $(11,66 \%, p<0,01)$ и юношей $(12,15 \%, p<0,01)$. Заключение. Относительно простая тренировка аэробной направленности 2 раза в неделю может оказать значительное воздействие на аэробную выносливость. Тренеры могут использовать данные наблюдения, чтобы научить курсантов, как организовывать и проводить тренировки самостоятельно.

Ключевые слова: курсанты полищии, правоохранительные органы, аэробные способности, физическая культура.

Кукич Филип, магистр, факультет спорта и физического воспитания, Белградский университет. Сербия, 11030, г. Белград, ул. Благоя Паровича, 156. E-mail: filip.kukic@gmail.com, ORCID: 0000-0002-8625-5375.

Коропановски Ненад, доцент, Университет уголовных расследований и полицейской подготовки. Сербия, 11080, г. Белград, ул. Кара Душана, 196. E-mail: nenad.koropanovski@kpu.edu.rs, ORCID: 0000-0002-7196-7185.

Янкович Радивое, доцент, Университет уголовных расследований и полицейской подготовки. Сербия, 11080, г. Белград, ул. Кара Душана, 196. E-mail: radivoje.jankovic@kpu.edu.rs, ORCID: 0000-0002-8902-2737.

Допсай Миливой, профессор, факультет спорта и физического воспитания, Белградский университет. Сербия, 11030, г. Белград, ул. Благоя Паровича, 156; профессор, Южно-Уральский государственный университет. 454080, г. Челябинск, проспект Ленина, 76. E-mail: milivoj.Dopsaj @gmail.com, ORCID: 0000-0001-7153-2993.

Поступила в редакцию 20 ноября 2019 z.

\section{ОБРАЗЕЦ ЦИТИРОВАНИЯ}

Effects of Specialized Physical Education and Additional Aerobic Training on Aerobic Endurance of Police Students / F. Kukić, N. Koropanovski, R. Janković, M. Dopsaj // Человек. Спорт. Медицина. - 2019. - Т. 19, № S2. - C. 58-64. DOI: 10.14529/hsm19s208

\section{FOR CITATION}

Kukić F., Koropanovski N., Janković R., Dopsaj M. Effects of Specialized Physical Education and Additional Aerobic Training on Aerobic Endurance of Police Students. Human. Sport. Medicine, 2019, vol. 19, no. S2, pp. 58-64. DOI: $10.14529 / \mathrm{hsm} 19 \mathrm{~s} 208$ 